\title{
Differences in Work Values by Gender and Generation: Evidence from Egypt
}

\author{
Maha Ahmed Zaki Dajani ${ }^{1}$ \\ ${ }^{1}$ Department of Business Administration, The British University in Egypt (BUE), Cairo, Egypt \\ Correspondence: Maha Ahmed Zaki Dajani, Department of Business Administration, The British University in \\ Egypt (BUE), Cairo, Egypt.
}

Received: January 17, 2018

Accepted: February 1, 2018

Online Published: February 8, 2018

doi:10.5430/ijba.v9n2p9

URL: https://doi.org/10.5430/ijba.v9n2p9

\begin{abstract}
This research was built on the previous research titled "The Mediating Role of Work Values in the Relationship between Islamic Religiosity and Job Performance: Empirical Evidence from Egyptian Public Health Sector" (2017) and continued to examine work values differences based on gender and generation. A quota sampling procedure was used to survey (400) participants in (10) public Egyptian hospitals. The positive response rate of the target population was (83.75\%). Work values were measured using Lyon Work Values Survey (LWVS) revised 25-item scale to assess four types of work values, namely, instrumental values, cognitive values, social/altruistic values, and prestige values. It also ranked the importance of each of these 25 -items according to gender and age. A confirmatory factor analysis, using AMOS 20, was conducted to confirm the factor structure of the used scale on the target population. The Findings revealed that there exists a similarity on the high importance of instrumental work values to both males and females, in all age groups. Dissimilarities are more apparent among other types of work values based on gender and generations. These results suggested that understanding work values differences based on these two demographic factors have a significant impact on the improvement of human resources practices and the development of management theory.
\end{abstract}

Keywords: work values, differences, gender, generations, public-sector, Egypt

\section{Introduction}

The purpose of this research is to investigate differences in work values based on gender and generation empirically in Egypt. This study is exploratory in nature, as there is no extant theoretical evidence to support the study's relevant hypotheses. It addresses three main research questions. First, to identify whether there are significant work value differences between working males and females, and, if so, to determine the nature of said differences. Second, to examine whether both factors of gender and generation are important demographic variables in the study of work values, or each should be considered in isolation of one another. Third, to check whether any observed gender-based differences in work value remains stable across generations, or alters from one generation to the other. Finally, to rank the importance of each work value with reference to gender and to age categories.

Based on (S. T. Lyons, Higgins, \& Duxbury, 2010) comprehensive work value model, it examined the importance of the four basic components of work values and ranked its revised 25-items in accordance to gender and age demographic factors.

In comparison to ample western studies that examined work values, only few studies have focused on the work values differences, in connection to gender and generation within the Egyptian public-sector working context. This study validated this scale in a non-western context.

\section{Literature Review}

\subsection{Conception of Work Values}

Since the 1970s, work values have played a major role in the development of vocational behavior theories and have become a key component in work adjustment theories (Dawis \& Lofquist, 1984) and career development models (Super \& Šverko, 1995). Researchers defined work values as generalized beliefs pertaining to the individual worker's conceptions of the desirable attributes of work and the work- related outcomes (Kalleberg, 1977; Knoop, 1994; S. T. Lyons, Duxbury, \& Higgins, 2006; S. T. Lyons et al., 2010). In reflection to the complexity of today's 
workplace, work values discern and prioritize various individual needs or goals that are addressed through one's work and working environment, including pay, job security, working hours, prestige, and self-actualization needs (Dose, 1997; Locke, 1976; Ros, Schwartz, \& Surkiss, 1999). These work values answered the question of what people thought was important in their working professions. Nevertheless, work values were more specific than general human values, but both were hierarchically ordered in the workers' minds according to their relative importance. Said hierarchy was then applied when making an important job or career decision(s) (Brown \& Crace, 1996). However, this did not imply that work values remained stable and were not subjected to change during the worker's life span. Investigating selected demographic factors, such as gender and age, triggered my academic interest as well as other researchers (Rioux \& Mokounkolo, 2013; Ueda \& Ohzono, 2013) to examine the impact of said factors on work values' differences. Aiming to be able to detect or even predict any possible attitudinal or behavioural alterations during the workers' career.

Despite the occurrence of global changes in workforce, empirical evidence for ranking the importance of work values based on gender and age categories remain scant and rather deficient especially in underdeveloped middle eastern countries, and especially in Egyptian academia.

Understanding in work values can provide management with valuable information for customizing their human resource interventions and designing matching incentives to ensure person-organization fit and avoid person-job mismatches and their negative consequences.

Based on (S. T. Lyons et al., 2010), work values indices applied in this study are classified into four groups and each work value is explained separately as follows:

Table 1

\begin{tabular}{ll}
\hline \multicolumn{1}{c}{ Instrumental } & \multicolumn{1}{c}{ Cognitive } \\
\hline Benefits & Challenge \\
Feedback & Continuously Learn \\
Job Security & Freedom \\
Hours of Work & Variety \\
Balance & Use Abilities \\
Information & Advancement \\
Salary & Achievement \\
Recognition & Interesting Work \\
Supportive Supervisor & \\
\hline \multicolumn{1}{c}{ Social/Altruistic } & \multicolumn{1}{c}{ Prestige } \\
\hline Co-Workers & Impact \\
Fun & Authority \\
Social Interaction & Prestigious \\
Help People & Influence \\
\hline
\end{tabular}


Table 2

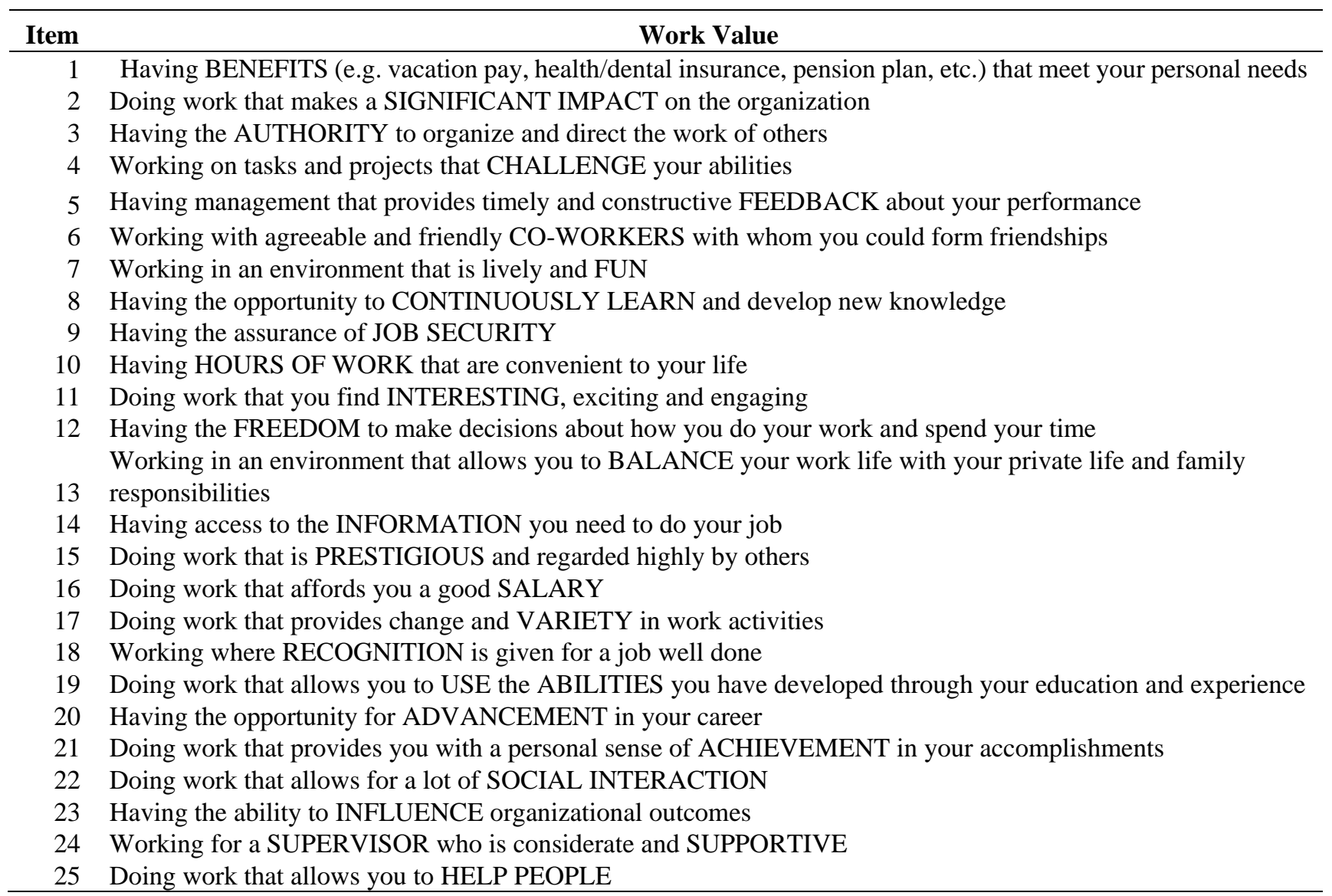

\subsection{Gender Differences in Work Values}

A number of studies have established that gender differences in work values are supported by two main theoretical rationale (Walker, Tausky, \& Oliver, 1982). One approach is the preemployment gender socialization approach and it continues throughout the individual's life (Beutell \& Brenner, 1986). Supporters of this approach argued that females and males are exposed to different socialization experiences, as a result, each gender develops different sets of work values, that in return, affects its work-related goals, priorities, and work practices (Betz, O'Connell, \& Shepard, 1989; Ismail, 2015; Veroff, 1977) Classically, females are taught to value social interactions and relationships, whilst males are taught to value power, achievement and career advancement (Bartol \& Manhardt, 1979; Rowe \& Snizek, 1995). The social-role theory is the second theoretical reasoning behind gender differences in work values. This gender stereotype theory supported the traditional division of labour between males and females, despite the multiple roles assigned to each one of them, as a spouse, parent, and employee (Nie, 2012). Males are responsible for providing financially for the family and engaging outside the house in breadwinning activities. On the other hand, females are socially expected to stay inside their homes, and to perform as primarily stay-in housewives, in charge of all domestic tasks and family responsibilities. Accordingly, females have developed similar work value preferences to those held by blue-collar workers, low-skilled laborers and poor quality job-holders (Kaufman \& Fetters, 1980). They rated instrumental/extrinsic work values higher (e.g. convenient working hours, social interaction with co-workers) and cognitive /intrinsic work values lower (e.g. challenge, achievement ; (Kaufman \& Fetters, 1980)).

Given the extremely limited scholarly research on this topic, these hypotheses may be purely speculative. However, I propose the following hypotheses:

Hypothesis 1: Working Egyptian women in the health public-sector attribute high emphasis on instrumental work values and give less importance to cognitive work values.

Hypothesis 2: Working Egyptian women in the health public-sector attribute high emphasis on social/altruistic work values and give less importance to prestige work values. 
Hypothesis 3: Working Egyptian women in the health public-sector rank higher preference to job security and work-life balance than working men in that same sector.

Hypothesis 4: Working Egyptian women in the health public-sector rank higher preference to social interaction and helping people than working men in that same sector.

\subsection{Generational Differences in Work Values}

Several authors have attempted to identify differently generations and age categorization (Birren \& Cunningham, 1985; Settersten Jr \& Mayer, 1997). For example, the most common is the chronological age which resembles the birth or calendar age, the biological age, which may be also called the physiological age, that reflects how well or poorly the body is functioning due to leading and managing certain life style measures. Also, the social age which resembles age expectations and social norms. In addition to the psychological age, which refers to the self-theories and the subjective age identification concept (Rioux \& Mokounkolo, 2013).

In this study, a 'generation' is defined as an identifiable group of people who has shared chronological age (birth years), age cohorts, have participated in significant life events at critical developmental stages during their life span, and witnessed the same political and socio-economical events, which then helped in the construction of their collective memory (Kupperschmidt, 2000; Wey Smola \& Sutton, 2002) (Dencker, Joshi, \& Martocchio, 2008; Noble \& Schewe, 2003; Twenge, Campbell, Hoffman, \& Lance, 2010). These life changing experiences not only distinguish between one generation and another, but they also tend to influence people' work values and work preferences (Gibson, Greenwood, \& Murphy Jr, 2009; Gursoy, Maier, \& Chi, 2008; S. Lyons \& Kuron, 2014).

A number of past studies pertaining to generational differences and their effects on work values used (Strauss \& Howe, 1991) demographic typology of generations and its contemporary modifications.

Cherrington (1980) studied the attitudes of three age groups (17-26, 27-39, 40-65 years) on a wide scale of work values criteria. The findings revealed that younger workers (17-26 years), when compared to the other two older groups attributed less importance to their sense of 'pride in craftsmanship' and to them it was acceptable to do a poor job, and were less keen to be of service to others (Wey Smola \& Sutton, 2002). Ueda and Ohzono (2013) showed that working persons in their 20s valued higher levels of power and authority and monetary rewards work values; whilst, working people in their 50s demonstrated higher levels of social contribution work values.

Based on the socio-economic perspective and supported by Maslow's hierarchy of needs theory it is often assumed that younger workers rate extrinsic/instrumental work values higher and intrinsic/cognitive work values lower than older generations. In his theory, Maslow identified different layers of human needs starting from physiological and safety needs, followed by needs for love and belonging, esteem and self-articulation, in which the lower-level needs must be satisfied before proceeding to the higher-level needs (Maslow, Frager, \& Fadiman, 1970). Similarly, (Inglehart, 1997) assumes in his 'scarcity hypothesis' that materialistic work values rate higher importance in underdeveloped countries and emerging economics, and that their significance will decrease with increasing national development and economic growth (Hauff \& Kirchner, 2015). This bears truth to the Egyptian underdeveloped socio-economic context.

However, in this research, generational differences are studied by dividing Egyptian working people's age into three generational groups. Younger junior generations in their mid-twenties till their mid-thirties (25-35 years). Middle-career generations who are in their mid-thirties till their mid-forties (36-45 years). Senior generations (46+ years) who are in their late forties approaching either early retirement (50 years) or the regular retirement age in the Egyptian labour law at the age of sixty.

Due to absence of substantial empirical research on this topic, these hypotheses may be purely speculative. However, I propose the following hypotheses:

Hypothesis 5: Younger junior generations working in the Egyptian public health sector attribute high emphasis on instrumental work values and less importance to cognitive work values.

Hypothesis 6: Middle career generations working in the Egyptian public health sector attribute high emphasis on cognitive work values and less importance to both prestige and social/altruistic work values.

Hypothesis 7: Senior generations working in the Egyptian public health sector attribute high emphasis on both prestige and social/altruistic work values.

Hypothesis 8: Younger junior generations working in the Egyptian public health sector rank higher importance to salary and benefits than other age groups. 
Hypothesis 9: Middle career generation working in the Egyptian public health sector rank higher importance to achievement and interesting job than other age groups.

Hypothesis 10: Senior generations working in the Egyptian public health sector rank higher importance to authority and helping people more than other age groups.

\section{Methodology}

\subsection{Population and Sampling Procedures}

Similar to the previous research empirical date (Dajani \& Mohamad, 2017) the target population in this study was health professionals working in public hospitals and public health facilities in Cairo-Egypt. A quota sampling procedure was used to recruit (400) participants in ten public hospitals working in greater Cairo area. Only (335) of them responded positively with a response rate of (83.75). Their main characteristics are shown in Table 3 .

Table 3. Sample characteristics

\begin{tabular}{lr}
\hline Characteristic & Description \\
\hline Age & $\mathrm{M}=39.64$ years \pm SD $=7.92$ years \\
Job Experience & $\mathrm{M}=13.72$ years $\pm \mathrm{SD}=5.36$ years \\
Gender & $52 \%$ \\
$\quad$ Male & $48 \%$ \\
Female & \\
Education & $51 \%$ \\
Bachelor Degree & $36 \%$ \\
Master Degree & $13 \%$ \\
Ph.D. & \\
\hline
\end{tabular}

These characteristics indicate a reasonable mix of demographic groups represented in the collected data.

\subsection{Measures}

The work values were measured using the 25-item scale adapted from (S. T. Lyons et al., 2010) to assess four types of work values, namely, instrumental values, cognitive values, social/altruistic values, and prestige values. The scale items were measured on a five-point Likert scale. Answers ranged from 1 (Strongly disagree) to 5 (Strongly agree).

Demographic variables including age, gender, educational level, and job experience were also assessed. Descriptive statistics, and reliability coefficient of these measures are shown in Table 4.

Table 4. Descriptive statistics and reliability coefficients of study variables

\begin{tabular}{lllc}
\hline Variable & Mean & SD & Cronbach's Alpha \\
\hline Work values & 112.74 & 9.87 & .875 \\
Instrumental & 42.91 & 3.76 & .729 \\
Cognitive & 31.21 & 2.48 & .756 \\
Social/Altruistic & 23.50 & 3.17 & .818 \\
Prestige & 14.12 & 2.67 & .822 \\
\hline
\end{tabular}

Furthermore, to test the validity of the used measures, the questionnaire was revised by a panel of 10 experts who assessed the content of each part and evaluated the appropriateness of this content to the Egyptian public sector working context. The comments of all experts indicated that the used questionnaires were valid and culturally appropriated. Moreover, a confirmatory factor analysis, using AMOS 20, was conducted to confirm the factor structure of the used scales within the target population. The fit indices for these factor structures are shown in Table 5. As can be shown in the previous table, all fit indices were above the recommended level of acceptance. Accordingly, it can be concluded that the factor structures of the used instruments were confirmed in the target population.

\subsection{Procedure}

Participants were approached in their clinics and health facilities at different Egyptian public hospitals and were asked to complete said questionnaire. Before completing the questionnaire, all participants were assured that their 
participation was voluntary, and anonymity was guaranteed. Latin square procedure was used to control the order of presenting this questionnaire and to minimize the common method bias.

Table 5. Fit indices for the factor structures of the used instrument

\begin{tabular}{lllllll}
\hline Variable & CMIN/DF & GFI & AGFI & NFI & CFI & RMSEA \\
\hline Instrumental Work values & 1.641 & .982 & .975 & .982 & .968 & .056 \\
Cognitive Work values & 1.352 & .984 & .978 & .983 & .971 & .041 \\
Social/Altruistic Work & 1.651 & .983 & .977 & .975 & .973 & .048 \\
$\begin{array}{l}\text { values } \\
\text { Prestige Work values }\end{array}$ & 1.888 & .962 & .958 & .961 & .961 & .055 \\
\hline
\end{tabular}

\subsection{Data Analysis and Results}

To test the first two hypotheses, assuming there are significant work values difference based on gender, a t-test procedure was conducted and revealed the following result.

Table 6. Work values differences based on gender

\begin{tabular}{llllll}
\hline Work values & $\begin{array}{l}\text { Males } \\
(\mathrm{n}=174)\end{array}$ & \multicolumn{3}{l}{$\begin{array}{l}\text { Females } \\
(\mathrm{n}=161)\end{array}$} & \multirow{2}{*}{ t-value } \\
\cline { 2 - 5 } & $\mathrm{M}$ & $\mathrm{SD}$ & $\mathrm{M}$ & $\mathrm{SD}$ & \\
\hline Instrumental Work values & 41.26 & 2.95 & 44.75 & 3.24 & $4.57 * *$ \\
Cognitive Work values & 31.38 & 2.64 & 30.76 & 2.81 & 1.68 \\
Social/Altruistic Work values & 12.56 & 2.43 & 16.11 & 3.17 & $3.72 * *$ \\
Prestige Work values & 15.89 & 2.59 & 12.36 & 2.73 & $3.63 * *$ \\
\hline
\end{tabular}

** significant at 0.01 level

Hypothesis (1) was supported. Working females gave higher importance to instrumental work values and less importance to cognitive work values compared to working males. These findings disagreed with the results of past studies (Clark, 2005; Hofstede, 2003; Konrad, Ritchie Jr, Lieb, \& Corrigall, 2000) that emphasized males' higher emphasis on instrumental/extrinsic work values than their female counterparts. However, both (Hirschi, 2010; Sharabi, 2014) confirmed that there is no gender differences in relation to emphasis on adequate monetary rewards and benefits. According to (Sharabi, 2014), Israeli women have become more materialistic as they attributed similar importance regarding pay and job security as men did. Hirschi (2010), on the other hand, confirmed the results of this study; that supported females' higher association to instrumental work values more than males.

In Egypt, due to the prevalence of challenging socio-economic needs and increasing poverty levels among average households, many females were driven to join the labor market and change their economic status form being mere in-house wives or even secondary breadwinners to becoming the main breadwinners like their male partners. They worked solely to earn money to live on and support their families. These female workers were forced to seek employment in the governmental public sector to ensure a steady flow of income as a buttress against insecurity of unemployment and inadequate or nonexistent financial support from male supporters and kin networks. Statistics in year 2010, revealed that females were concentrated in the government sector $(37.75 \%)$. This percentage of female employment in the government sector exceeded that of males $(19.31 \%)$, leading to feminization of the government sector.

(http://www1.aucegypt.edu/src/wsite1/research/research_economicparticipation.htm\#Work\%20Status\%20of\%20Wo men2010-accessed December 2017).

Hypothesis (2) was also supported. Working females attributed higher significance to social/altruistic work values and lesser importance to prestige work values compared to males. This is consistent with the classical stereotypical male and female work value patterns (e.g. prestige, authority, influence, and impact for men, whilst helping people, social interaction and fun for women). These findings appeared to be quite robust in keeping with the preemployment socialization and occupational socialization explanations, and what is valued as traditionally masculine or feminine work values. This result agreed with the study of (Ueda \& Ohzono, 2013) that supported the decisive effect of gender on the differences that occurred in power and authority work values. In Egypt, these gender preferential differences 
impacting these types of work values are evidenced not only by males' dominance in leadership positions, but also their intensity in occupations with better-paid jobs. On the other hand, women are still concentrated in the lower managerial ladder, and hold low skilled occupations. Relatively high percentage of working women occupy clerical professions, social services, teaching, nursing, and medical services.

To test hypotheses (3) and (4), referring to gender preferences for each single work value, Mann-Whitney test was used and indicated the following results:

Table 7. Means, ranking* and work values' differences according to gender

\begin{tabular}{llllll}
\hline Work values & Ranking & $\begin{array}{c}\text { Males } \\
(\mathrm{n}=174)\end{array}$ & Ranking & $\begin{array}{l}\text { Females } \\
(\mathrm{n}=161)\end{array}$ & z-value \\
\hline Benefits & $\mathbf{( 1 )}$ & 4.82 & $\mathbf{3})$ & 4.75 & 0.699 \\
Feedback & $(21)$ & 3.56 & $(15)$ & 4.74 & $2.30^{*}$ \\
Job security & $(19)$ & 3.72 & $\mathbf{( 1 )}$ & 4.85 & $2.58^{*}$ \\
Hours of work & $(20)$ & 3.64 & $\mathbf{( 2 )}$ & 4.77 & $3.57^{* *}$ \\
Balance & $(18)$ & 3.76 & $(6)$ & 4.68 & $2.61^{*}$ \\
Informational & $(10)$ & 4.45 & $(13)$ & 4.53 & 0.752 \\
Salary & $(4)$ & 4.72 & $(7)$ & 4.68 & 0.813 \\
Recognition & $(16)$ & 4.11 & $(4)$ & 4.75 & $1.99^{*}$ \\
Supportive superior & $(17)$ & 3.84 & $(9)$ & 4.62 & $2.43^{* *}$ \\
Challenge & $(9)$ & 4.45 & $(16)$ & 4.38 & 0.782 \\
Continuous learning & $(7)$ & 4.62 & $(11)$ & 4.58 & 0.643 \\
Freedom & $(21)$ & 4.48 & $(5)$ & 4.44 & 0.422 \\
Variety & $\mathbf{( 3 )}$ & 4.75 & $(17)$ & 4.36 & 0.875 \\
Use abilities & $(5)$ & 4.66 & $(14)$ & 4.51 & 0.512 \\
Advancement & $(\mathbf{2})$ & 4.78 & $(8)$ & 4.66 & 0.457 \\
Achievement & $(6)$ & 4.64 & $(12)$ & 4.57 & 0.481 \\
Interesting work & $(12)$ & 4.44 & $(10)$ & 4.61 & 0.562 \\
Co-workers & $(23)$ & 3.31 & $(21)$ & 4.04 & $2.51^{* *}$ \\
Fun & $(25)$ & 3.24 & $(20)$ & 4.11 & $2.78^{* *}$ \\
Social interaction & $(24)$ & 3.27 & $(19)$ & 4.25 & $2.66^{* *}$ \\
Help people & $(22)$ & 3.54 & $(18)$ & 4.31 & $2.43^{* *}$ \\
Impact & $(15)$ & 4.24 & $(25)$ & 3.67 & $2.21^{* *}$ \\
Authority & $(11)$ & 4.44 & $(24)$ & 3.74 & $2.64^{* *}$ \\
Prestigious & $(14)$ & 4.35 & $(22)$ & 3.84 & $2.23^{* *}$ \\
Influence & $(13)$ & 4.37 & $(23)$ & 3.76 & $2.35^{* *}$ \\
\hline
\end{tabular}

*Rank order scale (based on means), from ((1) highest position) to ((25) lowest position). ** significant at 0.01 level

Hypothesis (3) was supported. Working women ranked job security as number one in importance (means: men=3.72, women $=4.74, \mathrm{z}$ value $=2.58$ ) and convenient working hours as number two in importance (means: men=3.64, women $=4.77, \mathrm{z}$ value $=3.57$ ), higher than men. The study of (Krings, Nierling, Pedaci, \& Piersanti, 2009) have confirmed this result, and proven that long working hours is a noticeable male phenomenon, and flexible or discontinuous working hours is predominately a female phenomenon (Nie, 2012). Women prefer this flexible working arrangement so as to reconcile with their family obligations and responsibilities (Krings et al., 2009)

Men ranked Benefits (inclusive in most compensation packages) at the top place; whereas it ranked in the third place to women. Again, this supported the high emphasis on monetary and non-monetary rewards for both genders in Egyptian labor market, to survive within its rapidly depleting social security system and combat the rapid inflation of living expenses.

Hypothesis (4) was also supported. Although, working women ranked both social interaction and helping people as numbers nineteen and eighteen in importance, (means: $m e n=3.27$, women $=4.25$, $\mathrm{z}$ value $=2.66$ ) and (means: men $=3.54$, women $=4.31, \mathrm{z}$ value $=2.43$ ) respectively, but these work values were higher to females than males. However, this recent study revealed new changes in working women's work values preferences, compared to other studies, such as' (Clark, 2005; Konrad et al., 2000) that showed 'interesting work' with 'variety' were the most important work values 
to women than to men; also, instrumental values such as job security, salary, and autonomy were of higher importance to men than to women (Hofstede, 2001). Due to socio-economic hardships these work values stereotypically related to gender roles are currently fading in most middle-eastern countries. Many Egyptian women seeking to alleviate poverty and fill the monetary gaps in their households were compelled to join the labor market and engage in multiple socio-economical roles. Whilst struggling to fulfill their traditional female responsibilities (e.g. preparing food and raising children), they frequently carried over the burdens of economic livelihood of the household and became the main breadwinners like men.

To test age hypotheses numbered (5), (6) to (7) assuming there are significant work values differences based on age categories, an ANOVA procedure was conducted and revealed the following results:

Table 8. Difference in work values based on age categories

\begin{tabular}{|c|c|c|c|c|c|c|c|}
\hline \multirow[t]{2}{*}{ Work values } & \multicolumn{2}{|c|}{$\begin{array}{l}\text { Juniors } \\
25-35 \text { years } \\
(\mathrm{n}=120)\end{array}$} & \multicolumn{2}{|c|}{$\begin{array}{l}\text { Mid-career } \\
36-45 \text { years } \\
(\mathrm{n}=110)\end{array}$} & \multicolumn{2}{|c|}{$\begin{array}{l}\text { Seniors } \\
46+\text { years } \\
(\mathrm{n}=105)\end{array}$} & \multirow[t]{2}{*}{$\begin{array}{l}\text { F-val } \\
\text { ue }\end{array}$} \\
\hline & $\mathrm{M}$ & SD & $\mathrm{M}$ & $\mathrm{SD}$ & $\mathrm{M}$ & SD & \\
\hline Instrumental work values & 42.95 & 3.59 & 42.78 & 3.62 & 42.62 & 3.25 & 1.362 \\
\hline Cognitive work values & 31.44 & 2.57 & 31.68 & 2.37 & 31.11 & 3.64 & 1.553 \\
\hline Social/Altruistic work-values & 13.55 & 3.21 & 13.19 & 3.18 & 13.41 & 3.08 & 1.433 \\
\hline Prestige work values & 14.02 & 2.63 & 14.55 & 2.31 & 14.61 & 2.24 & 1.137 \\
\hline
\end{tabular}

Hypotheses 7, 8 and 9 were partially supported in this sample. Results in table 8 have displayed slight significant differences in work values based on age demographic factor. Findings revealed the following: first, levels of instrumental work values decreased as working people aged. Second, mid-career staff demonstrated higher cognitive work values than all other working generations. Third, junior staff showed exceptionally higher social/altruistic work values than mid-careered and senior working people. Fourth, senior staff rated high levels in prestige work value than other generations. The reasons behind the formulation of this pattern may be attributed to the fact that younger generations need instrumental rewards more to build up their professional careers and start new families; whilst senior member value higher levels of power and prestige in their workplaces due to their experiences and long record of career accomplishments. Mid-career working staff concentrated on high levels of cognitive work values to undertake challenging tasks and to accomplish promising career goals. Surprisingly, younger junior generation scored high levels in social/altruistic work values. This can be explained by their youth self-motivation incentives as younger junior generations working in the health public sector. They aimed to serve their society and their organizations and act as stewards of the public interest (Kernaghan, 2000, 2003; Van Wart, 1998) in order to guarantee a better future for them and the coming generations.

To test hypotheses (8), (9) and (10), referring to ranking the importance of each work value for junior, mid-career and senior working people, Kruskal-Wallis test (Kruskal \& Wallis, 1952) was used and indicated the following results: 
Table 9. Means, ranking and work values' differences according to age

\begin{tabular}{|c|c|c|c|c|c|c|c|}
\hline Work values & Ranking & $\begin{array}{c}\text { Juniors } \\
(25-35) \text { years } \\
(\mathrm{n}=120) \\
\end{array}$ & Ranking & $\begin{array}{c}\text { Mid-career } \\
(36-45) \text { years } \\
(\mathrm{n}=110)\end{array}$ & Ranking & $\begin{array}{c}\text { Seniors } \\
(46+) \text { years } \\
(\mathrm{n}=105) \\
\end{array}$ & $\chi^{2}$ \\
\hline Benefits & (5) & 4.55 & (8) & 4.51 & (7) & 4.48 & 2.51 \\
\hline Feedback & (8) & 4.47 & (13) & 4.38 & (15) & 4.32 & 2.22 \\
\hline Job security & (3) & 4.61 & (5) & 4.54 & (1) & 5.47 & 2.41 \\
\hline Hours of work & (12) & 4.36 & (13) & 4.41 & (12) & 4.38 & 2.71 \\
\hline Balance & (7) & 4.52 & (9) & 4.47 & (9) & 4.43 & 2.64 \\
\hline Informational & (15) & 4.22 & (17) & 4.16 & (17) & 4.18 & 1.84 \\
\hline Salary & (2) & 4.62 & (3) & 4.58 & (5) & 4.53 & 1.98 \\
\hline Recognition & (10) & 4.43 & (4) & 4.55 & (3) & 4.59 & 2.16 \\
\hline Supportive superior & (4) & 4.59 & (12) & 4.43 & (13) & 4.38 & 2.43 \\
\hline Challenge & (1) & 4.64 & (6) & 4.54 & (10) & 4.41 & 2.31 \\
\hline Continuous learning & (13) & 4.32 & (10) & 4.45 & (11) & 4.41 & 2.24 \\
\hline Freedom & (9) & 4.47 & (2) & 4.63 & (4) & 4.58 & 2.44 \\
\hline Variety & (16) & 4.18 & (15) & 4.37 & (14) & 4.35 & 2.73 \\
\hline Use abilities & (11) & 4.43 & (7) & 4.54 & (8) & 4.48 & 2.66 \\
\hline Advancement & (17) & 4.18 & (16) & 4.26 & (16) & 4.28 & 1.81 \\
\hline Achievement & (6) & 4.53 & (1) & 4.64 & (2) & 4.71 & 2.11 \\
\hline Interesting work & (14) & 4.29 & (11) & 4.44 & (6) & 4.51 & 2.14 \\
\hline Co-workers & (20) & 3.38 & (24) & 3.12 & (24) & 3.31 & 1.96 \\
\hline Fun & (19) & 3.52 & (22) & 3.33 & (21) & 3.48 & 2.11 \\
\hline Social interaction & (22) & 3.25 & (25) & 3.01 & (25) & 3.18 & 2.26 \\
\hline Help people & (18) & 3.64 & (20) & 3.44 & (19) & 3.56 & 2.51 \\
\hline Impact & (23) & 3.21 & (21) & 3.35 & (22) & 3.42 & 2.35 \\
\hline Authority & (21) & 3.33 & (18) & 3.54 & (20) & 3.55 & 2.46 \\
\hline Prestigious & (24) & 3.16 & (23) & 3.27 & 23 & 3.36 & 2.41 \\
\hline Influence & (25) & 3.21 & (19) & 3.45 & 18 & 3.61 & 2.37 \\
\hline
\end{tabular}

*Rank order scale (based on means), from ((1) highest position) to ((25) lowest position). ** significant at 0.01 level

Hypothesis (8) was partially supported. Younger junior generations ranked first 'challenge', followed by 'salary', then 'job security'.

Hypothesis (9) was partially supported. Mid-career generations ranked first 'achievement' followed by 'freedom' then 'salary'.

Hypothesis (10) was rejected. Senior generations ranked first 'job security', followed by 'achievement', then recognition.

It is difficult to determine reasons why different generations possessed different work values. One possible reason is people's work values changed as they matured and gained more personal and professional experiences. At first, it is all about economic survival and monetary rewards 'work to live'. Then the new millennium junior generations desired more than basic needs (Lancaster \& Stillman, 2004). They valued meaning in work (Arnett, 2007; Tulgan, 2009); they aspired to 'live to work' on tasks and projects that challenge their abilities. That explains why strategic human resources management plans in successful multinationals and reputable local companies are structured to highlight retention policies that emphasize younger employees' career challenges and career growth.

Egypt's public sector has recently witnessed severe waves of job cuts and early severance incentives for its public sector senior staff aging in their mid/late forties. It was partially a national policy to administer health reform programs and minimize the overpopulated public sector by encouraging early pension packages. The downsizing, re-structuring and instability deleted the presence of a 'lifetime secured job' to this age group; that may explain why senior people aged (46+) ranked highest importance to job security.

Altruistic/social work values ranked low in importance to the population of this sample. The socio-economic hardships, increased individualism and even narcissism over the generations (Twenge \& Campbell, 2008) have lessened the interest in altruistic/social work rewards worldwide. Despite, the spread of social media and technological networking 
sites that may apparently create the impression that people want to connect, help one another, and participate in social good; however, empirical research has documented the breakdown in social relationships and traced the perish of many social collegiality work values. (McPherson, Smith-Lovin, \& Brashears, 2006; Twenge et al., 2010).

\section{Implication for Management}

Understanding and utilizing work values differences based on demographic factors, such as gender and generations may impact the perceived person-organization fit within the organizations. Moreover, it could enable rational managerial decisions to place the 'right person, in the right place, at the right time'. Resulting in the enhancement of employees' positive attitudes towards work, increased performance, increased organizational commitment, and improved team cohesion within the workplace.

\section{Limitation of the Study and Avenues for Future Research}

Because of the limited amount of empirical research in this area, my research questions were somewhat exploratory. Further research should build on these findings, exploring other demographic factors and analyzing the causes and consequences of work values differences. More research need to be conducted cross-sectional and across time to be able to generalize these results within the Egyptian context.

\section{References}

Arnett, J.J. (2007). Emerging adulthood: What is it, and what is it good for?. Child Development Perspectives, 1(2), 68-73. https://doi.org/10.1111/j.1750-8606.2007.00016.x

Bartol, K.M., \& Manhardt, P.J. (1979). Sex differences in job outcome preferences: Trends among newly hired college graduates. Journal of Applied Psychology, 64, 477. https://doi.org/10.1037/0021-9010.64.5.477

Betz, M., O'Connell, L., \& Shepard, J.M. (1989). Gender differences in proclivity for unethical behavior. Journal of Business Ethics, 8(5), 321-324. https://doi.org/10.1007/978-94-007-4126-3_20

Beutell, N.J., \& Brenner, O.C. (1986). Sex differences in work values. Journal of Vocational Behavior, 28(1), 29-41. https://doi.org/10.1016/0001-8791(86)90037-0

Birren, J.E., \& Cunningham, W.R. (1985). Research on the psychology of aging: Principles, concepts and theory.

Brown, D., \& Crace, R.K. (1996). Values in life role choices and outcomes: A conceptual model. The Career Development Quarterly, 44(3), 211-223. https://doi.org/10.1002/j.2161-0045.1996.tb00252.x

Cherrington, D.J. (1980). The Work Ethic: Working Values And Values That Work. Amacom.

Clark, A.E. (2005). Your money or your life: Changing job quality in OECD countries. British Journal of Industrial Relations, 43(3), 377-400. https://doi.org/10.1111/j.1467-8543.2005.00361.x

Dajani, M.A.Z., \& Mohamad, M.S. (2017). The Mediating Role of Work Values in the Relationship between Islamic Religiosity and Job Performance: Empirical Evidence from Egyptian Public Health Sector. Journal of Business Theory and Practice, 5(4), 293. http://dx.doi.org/10.22158/jbtp.v5n4p293

Dawis, R.V., \& Lofquist, L.H. (1984). A psychological theory of work adjustment: An individual-differences model and its applications. University of Minnesota Press.

Dencker, J.C., Joshi, A., \& Martocchio, J.J. (2008). Towards a theoretical framework linking generational memories to workplace attitudes and behaviors. Human Resource Management Review, 18(3), 180-187. https://doi.org/10.1016/j.hrmr.2008.07.007

Dose, J.J. (1997). Work values: An integrative framework and illustrative application to organizational socialization. Journal of Occupational and Organizational Psychology, 70(3), 219-240. https://doi.org/10.1111/j.2044-8325.1997.tb00645.x

Gibson, J.W., Greenwood, R.A., \& Murphy Jr, E.F. (2009). Generational differences in the workplace: Personal values, behaviors, and popular beliefs. Journal of Diversity Management, 4(3), 1. Retrieved from https://search.proquest.com/jsessionid=5C228B1D412DFD78E9E0DEC7051801AD.i-0ebb638f4d598a2b9

Gursoy, D., Maier, T.A., \& Chi, C.G. (2008). Generational differences: An examination of work values and generational gaps in the hospitality workforce. International Journal of Hospitality Management, 27(3), 448-458. https://doi.org/10.1016/j.ijhm.2007.11.002

Hauff, S., \& Kirchner, S. (2015). Identifying work value patterns: cross-national comparison and historical dynamics. International Journal of Manpower, 36(2), 151-168. https://doi.org/10.1108/JJM-05-2013-0101 
Hirschi, A. (2010). Positive adolescent career development: The role of intrinsic and extrinsic work values. The Career Development Quarterly, 58(3), 276-287. https://doi.org/10.1002/j.2161-0045.2010.tb00193.x

Hofstede, G. (2001). Culture's recent consequences: Using dimension scores in theory and research. International Journal of Cross Cultural Management, 1(1), 11-17. https://doi.org/10.1177/147059580111002

Hofstede, G. (2003). Culture's consequences: Comparing values, behaviors, institutions and organizations across nations. Sage publications.

Inglehart, R. (1997). Modernization and postmodernization: Cultural, economic, and political change in 43 societies. Princeton University Press.

Ismail, H. (2015). Gender differences in personal values: a business perspective. International Journal of Commerce and Management, 25(4), 687-698. https://doi.org/10.1108/IJCoMA-10-2013-0104

Kalleberg, A.L. (1977). Work values and job rewards: A theory of job satisfaction. American Sociological Review, 124-143. https://doi.org/10.2307/2117735

Kaufman, D., \& Fetters, M.L. (1980). Work motivation and job values among professional men and women: A new accounting. Journal of Vocational Behavior, 17(3), 251-262. https://doi.org/10.1016/0001-8791(80)90021-4

Kernaghan, K. (2000). The post-bureaucratic organization and public service values. International Review of Administrative Sciences, 66(1), 91-104. https://doi.org/10.1177/0020852300661008

Kernaghan, K. (2003). Integrating values into public service: The values statement as centerpiece. Public Administration Review, 63(6), 711-719. https://doi.org/10.1111/1540-6210.00334

Knoop, R. (1994). Work values and job satisfaction. The Journal of psychology, 128(6), 683-690. https://books.google.com.eg/books?id=bgsiAQAAMAAJ

Konrad, A.M., Ritchie Jr, J.E., Lieb, P., \& Corrigall, E. (2000). Sex differences and similarities in job attribute preferences: a meta-analysis. Psychological Bulletin, 126(4), 593. https://doi.org/10.1037/0033-2909.126.4.593

Krings, B.J., Nierling, L., Pedaci, M., \& Piersanti, M. (2009). Working time, gender and work-life balance. Katholieke Universiteit Leuven, HIVA.

Kruskal, W.H., \& Wallis, W.A. (1952). Use of ranks in one-criterion variance analysis. Journal of the American statistical Association, 47(260), 583-621. https://books.google.com.eg/books?isbn=0470770740

Kupperschmidt, B.R. (2000). Multigeneration employees: strategies for effective management. The Health Care Manager, 19(1), 65. Retrieved from https://www.ncbi.nlm.nih.gov/pubmed/11183655

Lancaster, L.C., \& Stillman, D. (2004). When generations collide: how to solve the generational puzzle at work. Paper presented at the The Management Forum Series. Retrieved from washingtonandco.com/pdf/when_generations_collide.pdf

Locke, E.A. (1976). The nature and causes of job satisfaction. Handbook of Industrial And Organizational Psychology. Retrieved from https://books.google.com.eg/books?id=JWYPAQAAMAAJ

Lyons, S., \& Kuron, L. (2014). Generational differences in the workplace: A review of the evidence and directions for future research. Journal of Organizational Behavior, 35(S1). Retrieved from https://books.google.com.eg/books?isbn=178635263X

Lyons, S.T., Duxbury, L.E., \& Higgins, C.A. (2006). A comparison of the values and commitment of private sector, public sector, and parapublic sector employees. Public Administration Review, 66(4), 605-618. Retrieved from https://books.google.com.eg/books?isbn=1783476583

Lyons, S.T., Higgins, C.A., \& Duxbury, L. (2010). Work values: Development of a new three-dimensional structure based on confirmatory smallest space analysis. Journal of Organizational Behavior, 31(7), 969-1002. Retrieved from https://books.google.com.eg/books?isbn=1137467819

Maslow, A.H., Frager, R., \& Fadiman, J. (1970). Motivation and personality. Harper \& Row New York. Retrieved from https://books.google.com.eg/books?isbn=1317363744

McPherson, M., Smith-Lovin, L., \& Brashears, M.E. (2006). Social isolation in America: Changes in core discussion networks over two decades. American Sociological Review, 71(3), 353-375. Retrieved from https://books.google.com.eg/books?isbn=1317615263 
Nie, L. (2012). Gender differences in work values in China. Clemson University. Retrieved from https://tigerprints.clemson.edu/cgi/viewcontent.cgi?article $=2474 \&$ context $=$ all

Noble, S.M., \& Schewe, C.D. (2003). Cohort segmentation: An exploration of its validity. Journal of Business Research, 56(12), 979-987. Retrieved from https://books.google.com.eg/books?isbn=184541540X

Rioux, L., \& Mokounkolo, R. (2013). Investigation of subjective age in the work context: study of a sample of French workers. Personnel Review, 42(4), 372-395. https://doi.org/10.1108/PR-01-2011-0009

Ros, M., Schwartz, S.H., \& Surkiss, S. (1999). Basic individual values, work values, and the meaning of work. Applied Psychology, 48(1), 49-71. https://books.google.com.eg/books?isbn=0863779948

Rowe, R., \& Snizek, W.E. (1995). Gender differences in work values: Perpetuating the myth. Work and Occupations, 22(2), 215-229. https://books.google.com.eg/books?isbn=1473971330

Settersten Jr, R.A., \& Mayer, K.U. (1997). The measurement of age, age structuring, and the life course. Annual Review Of Sociology, 23(1), 233-261. https://books.google.com.eg/books?isbn=3319208802

Sharabi, M. (2014). Life Domains Preferences among Women and Men: The Effect of Demographic Variables. International Labour Review. Retrieved from https://www.researchgate.net/.../293314931_Sharabi_-_Life_domain_preferences_amon

Strauss, W., \& Howe, N. (1991). Generations: The history of America's future, 1584 to 2069. New York. Retrieved from https://books.google.com.eg/books?id=oOztAAAAMAAJ

Super, D.E., \& Šverko, B.E. (1995). Life roles, values, and careers: International findings of the Work Importance Study. Jossey-Bass. Retrieved from https://books.google.com.eg/books?isbn=1402062303

Tulgan, B. (2009). Not everyone gets a trophy: How to manage generation. Y: John Wiley \& Sons. Retrieved from https://books.google.com.eg/books?isbn=0470442794

Twenge, J.M., \& Campbell, S.M. (2008). Generational differences in psychological traits and their impact on the workplace. Journal of Managerial Psychology, 23(8), 862-877. https://doi.org/10.1108/02683940810904367

Twenge, J.M., Campbell, S.M., Hoffman, B.J., \& Lance, C.E. (2010). Generational differences in work values: Leisure and extrinsic values increasing, social and intrinsic values decreasing. Journal of Management, 36(5), 1117-1142. https://books.google.com.eg/books?isbn=1137467819

Ueda, Y., \& Ohzono, Y. (2013). Differences in Work Values by Gender, Marital Status, and Generation: An Analysis of Data Collected from Working Persons Survey, 2010. International Journal of Human Resource Studies, 3(2), 28. https://doi.org/10.5296/ijhrs.v3i2.3131

Van Wart, M. (1998). Changing public sector values (Vol. 1045). Taylor \& Francis.

Veroff, J. (1977). Process vs. impact in men's and women's achievement motivation. Psychology of Women Quarterly, 1(3), 283-293. https://doi.org/10.1111/j.1471-6402.1977.tb00555.x

Walker, J.E., Tausky, C., \& Oliver, D. (1982). Men and women at work: Similarities and differences in work values within occupational groupings. Journal of Vocational Behavior, 2l(1), 17-36. https://doi.org/10.1016/0001-8791(82)90050-1

Wey Smola, K., \& Sutton, C.D. (2002). Generational differences: Revisiting generational work values for the new millennium. Journal of Organizational Behavior, 23(4), 363-382. https://doi.org/10.1002/job.147 